ISSN 1822-8402 EUROPEAN INTEGRATION STUDIES. 2014. No. 8

\title{
PATTERN OF FINANCIAL FLOWS WITHIN THE EUROPEAN UNION: FIRST INSIGHTS ABOUT CREDITOR-DEBTOR COUNTRY RELATIONSHIP
}

\author{
Rasa Daugeliene \\ Kaunas University of Technology, \\ Faculty of Social Sciences, Arts and Humanities \\ Institute of Europe \\ Mickevicius str. 37, LT- 44320, Lithuania \\ e-mail: rasa.daugeliene@ktu.lt
}

Pawel Mlodkowski

University of Information Technology and Management in Rzeszow

2 Sucharskiego Street, 35-255 Rzeszow

Republic of Poland

e-mail: pawel.mlodkowski@gmail.com

cross $^{\text {ref }}$ http://dx.doi.org/10.5755/j01.eis.0.8.7014

The paper presents an explanation for accumulation of foreign liabilities referring to herd behavior fueled by the Common Market mechanism allowing for some role by the New Member States of 2004. Citizens of the new EU member states of 2004 started to diversify asset portfolios available within the Common Market. Residents of other EU regions observed additional outright demand for real estate, which created appreciation expectations. They took, therefore, long positions in this market. However, speculative transactions were mostly financed by imported capital from EU-creditor countries. Foreign liabilities of PIIGS countries systematically grew. The authors observe asymmetry in terms of EU-creditor engagement in this process. The real estate market in some EU regions experienced a boom from 2004 to 2008. It was started by cash holders (foreigners) and became later leverage-fuelled by residents. When external buyers disappeared from the real estate markets, the appreciation impulse for real assets associated with the foreigners vanished. Locals in found themselves in long positions in significantly inflated real assets without any chance for recovering the original cost due to deficient demand. When explaining the reasons for intra-EU financial flows authors offer EU-solidarity interpretation in the spirit of Tirole (2012). Considering mentioned the scientific problems were raised: how the pattern or scope of financial flows in the EU could be evaluated? What is the relation between creditor - debtor considering investment in real estate in PIGS countries? The aim is to present and discuss about the pattern of financial flows within the European Union (between creditor countries - Germany, France, the UK; and debtor countries - PIIGS) and to propose a mechanism for building up real assets boom. In order to reach the aim four tasks are to be solved: briefly present the milestones of financial flows liberalization in the European Union; provide methodological substantiation of empirical investigation of the intra-EU (between creditor countries - Germany, France, the UK; and debtor countries - PIIGS) financial flows; present considerations about the problem with capital flows in European Union; to analyze the situation of financial flows in creditor and debtor countries as well as to present stylized insights about creditor-debtor relationship considering investment in real estate in PIIGS countries. Research methods: empirical investigation defining variables that describe the object of investigation; BOP statistics, ECB database as well as IMF and IFS statistics was used as source of information. The authors try to observe the international investment position defined for bilateral positions between creditor (Germany, France, the UK) and debtor countries (PIGS). The restriction of analysis of financial flows pattern was made to only several of the EU countries (Germany, France and the UK, as creditors and PIGS group: Portugal, Italy, Greece, Spain). Motivation for this decision is based on the following observations, that there are only few countries that we recognize as the EU-based debtors. These are those EU-members that experienced debt-related problems. The main results of the research - offered an alternative approach to understanding a fraction of the debt created due to Common Market and European Financial Area. Analysis of situation of financial flows in creditor and debtor countries as well as stylized insights about creditor-debtor relationship considering investment in real estate in PIGS countries was provided. Alternative scenario (four steps) as an explanation of the mechanism behind the process of foreign liabilities accumulation in the EU before the debt crisis of 2009 was presented as well.

Keywords: debt crisis, financial flows, balance of payments, IIP, European Union.

\section{Introduction}

The post-crisis period witnessed multitude of research initiatives aimed at explaining variety of issues associated with causes and consequences of financial turmoil. In the

literature, one could recognize several most popular topics. Their popularity results from their significance for economic policy: (1) the role of debt [private and public] in the economic 
downturn, (2) financial intermediaries and regulation of their international activities, (3) international capital flows and their role in generating aggravating and prolonging the debt crisis.

The article offers an original explanation supported by an empirical investigation of the intra-EU financial flows (by referring to the private investments in real estate in PIIGS countries). This presupposes the novelty of the article. It will be left for further studies to present a formal theoretical model for the evaluation of behavior of agents considering different investment decisions. The EU-citizens optimizing their utility functions in the long run may present more solidarity with fellow members of the EU than with citizens of the rest of the world. This, in turn, allows for postponing repayment, as the credibility of the EU-based debtors is, in some respect, enhanced by the fact of the EU-membership. Other Authors (Spiegel, 2008; Waysand, Ross, \& De Guzman, 2012; Lane, 2012; Lane, 2006) may underestimate belief in the EUinstitutions and the EU legal framework, when explaining observed behavior and international capital flows (within the EU). There is only one, up to date, explicit attempt to capture specific relationships in a model describing some form of solidarity between countries that belong to a regional economic integration association (Tirole, 2012).

These statements first presuppose to raise scientific problems: how the pattern or scope of financial flows in the EU could be evaluated? What is the relation between creditor - debtor considering investment in real estate in PIIGS countries?

The aim of the paper is to present and discuss about the pattern of financial flows within the European Union (between creditor countries - Germany, France, the UK; and debtor countries - PIIGS) and to propose a mechanism for building up real assets boom.

In order to reach the aim four tasks are to be solved:

- briefly present the milestones of financial flows liberalization in the European Union;

- provide methodological substantiation of empirical investigation of the intra-EU (between creditor countries - Germany, France, the UK; and debtor countries - PIIGS) financial flows;

- present considerations about the problem with capital flows in European Union;

- to analyze the situation of financial flows in creditor and debtor countries as well as to present stylized insights about creditor-debtor relationship considering investment in real estate in PIGS countries.

Research methods: empirical investigation defining variables that describe the object of investigation; BOP statistics, ECB database as well as IMF and IFS statistics was used as source of information.

The main results of the research - offered an alternative approach to understanding a fraction of the debt created due to Common Market and European Financial Area. The study was focused on countries suffering from excessive external private debt that have been members of the Eurozone. Analysis of situation of financial flows in creditor and debtor countries as well as stylized insights about creditor-debtor relationship considering investment in real estate in PIGS countries was provided. Alternative scenario (four steps) as an explanation of the mechanism behind the process of foreign liabilities accumulation in the EU before the debt crisis of 2009 was presented as well.

\section{Milestones of Financial Flows Liberalization in the European Union}

Free movement of capital belongs to fundamental principles of the European Union. It seems to be one of necessary conditions to reach political and economic community of all Member States, as full liberalization of "Capital Movements" was included in the Article 67 of the Treaty of Rome in 1957 (EC 1957). Then, effective integration of "Capital Movements" was among Directives of the Single European Act in 1988. In 1990, free movement of capital became mandatory. During the Madrid European Council 1997-1998, regulatory framework for capital markets was established. Another meaningful milestone for free capital movements was the introduction of Euro on the $1^{\text {st }}$ of January 1999. And then, under Lisbon Program of 2008-2010, one of objectives defined was an effective integration of financial services. Summarizing the historical background it could be find July 1990 as the moment of full liberalization of capital movements between Member States. However, establishing European Financial Area required further, progressive liberalization, which covered capital operations in financial market securities and operations involving financial credits.

It is worth to mention that the European Union foreseen potential problems resulting from international capital flows and created a special legal framework for dealing with international liquidity issues. Financial assistance is offered in a form of loans to be granted up to 12 billion EUR. The European Commission, on behalf of the European Community, contracts on the capital markets or with financial institutions these loans. There is also an alternative scheme for cases requiring quick response. Support is available by the European Central Bank. This option however is restricted under very short-term financing facility program.

\section{Methodological Substantiation of Empirical Investigation of the intra-EU Financial Flows}

The empirical investigation of the intra-EU financial flows starts with defining variables that describe the phenomenon we wish to study. The first idea is to refer to the Balanceof-Payments and International Investment Position statistics. First, we look at aggregated data presenting bilateral net positions (assets minus liabilities) for few pairs of countries. Then, we investigate changes in the pattern three main categories of foreign investment developed over the period 2001-2009. The BOP statistics is a source of information about three main categories of financial flows that together represent the core subject of our analysis. These are: direct investment, portfolio investment, and other investment. Financial flows that are recorded as direct investment represent investment in the ownership of domestic real assets and companies by foreign investors interested in the longterm engagement and in influence on management. There are other recent studies (Desatnicov \& Akiba, 2013) that deal with this category of international financial flows. They try to recognize factors driving the FDI using vast sets of panel data. Desatnicov \& Akiba (2013) show empirically that political 
risk factor is significant for the FDI flows. As such, this result supports assumption that intra-EU financial flows are facilitated by the fact of the EU membership of debtors and creditors, and the resulting lower political risk for any forms of foreign investment. Two other kinds of foreign financial flows, namely portfolio investment and other investment have potentially significant role in creating private and public holdings of debt issued by residents of a foreign country. Portfolio investment represents financial flows resulting from transactions of purchasing financial instruments like shares (up to $5 \%$ of total number of shares outstanding) and debt instruments, like bonds.

One should be also aware of the fact that 'other investment' category must also be decomposed in order to retrieve the necessary information on the debt holdings. This particular category of financial flows covers a broad fraction that represents trade credit extended in foreign trade. Having no role in the debt crisis in the EU, this form of foreign indebtness represents no interest for this study, and shall be omitted in the empirical exercise. The rest of 'other investment' category represents mostly transactions with domestic banking sector, and is of high importance for our study.

For the purpose of empirical investigation, we refer to the ECB database on the EU balance of payments for selected countries that represent our subject here. Main source of time series is however the on-line database by the International Monetary Fund, the IFS. Some information is retrieved from a separate dataset on trade and investment. Annual time series cover assets and liabilities in pairs of countries over the period 2001-2009. We try to observe the international investment position defined for bilateral positions between creditor (Germany, France, the UK) and debtor countries (PIGS).

Why do we restrict our analysis of the financial flows pattern to only several of the EU countries (Germany, France and the UK, as creditors and PIGS group: Portugal, Italy, Greece, Spain)? Motivation for this decision is based on the following observations. There are only few countries that we recognize as the EU-based debtors. These are those EUmembers that experienced debt-related problems like (1) insolvency, (2) debt repayment rescheduling, and (3) credit rating degrading (Reis, 2013). The idea to cover other, or all EU countries in this group does not seem to be reasonable. First, there must be another group of those that extended loans to the EU-debtors, as we intend to study only the intra-EU financial flows. Second, the new EU-members are still not able to provide substantial financing due to relatively lower levels of income, and in the same time these countries do not seem to be able to create excessive private and public debt due to cultural and institutional barriers. However, one new member state is included in the empirical analysis to some extent, but it is neither a debtor nor a creditor in our story.

There is a multitude of studies that cast sets of socioeconomic factors against international capital flows (Desatnicov \& Akiba, 2013; Forbes \& Warnock, 2012; Borio, McCauley, \& McGuire, 2011), but some most recent publications undermine the importance of any variables capturing macroeconomic factors on both sides of these flows (Geanakoplos, 2009; Lane, 2010). In particular, Lane \& Milesi-Feretti, (2012) suggest that behavior of the current account balance in the period 2005-2008 has not been shaped by any observable developments of macroeconomic variables. These observations, based on systematic investigations, indicate that foreign creditors acted without considering the classical factors reflecting ability to recover the capital they provided. From the ancient times creditors used to monitor closely variables that describe debtor activities and the resulting financial position. However, in case of the debtors of the PIIGS group, EU-based creditors neglected to observe developments that signaled moral hazard and irresponsibility of the private and public borrowers (Barnes, 2010). This, in turn, allows for posing a hypothesis on the drivers of the intraEU capital flows that is the core scientific question we try to address here.

Lane (2013, p. 10) claims that this discreet increase in the current account dispersion over the period 2003-2007 is ' $a$ very unusual phase in the history of international capital flows'. We do not agree with this simple explanation that the observed net imbalances resulted from a combination of (1) a perceived reduction in financial risk, and (2) a perceived improvement in the ability of the financial system to absorb risk events. According to Lane (2013), these two factors were responsible for making net capital flows more sensitive to macroeconomic fundamentals. This is somehow inconsistent with empirical studies (Lane \& Milesi-Feretti, 2012), by this particular author. There is also blame on the same set of factors for facilitating the leverage-fuelled property booms in some countries that we study here.

\section{Considerations about the Problem with Capital Flows in European Union}

The original perception of the cause-consequence or, the co-occurrence when current account imbalance is considered binds this variable with growth and growth expectations. It has been present in the literature on emerging economies that even a deep deficit is acceptable, as it is a necessary by-product of quick economic transformation (Brown \& Lane, 2011). The idea supporting this approach to dangerous, and unacceptable, otherwise, external position is based on several assumptions. Discussing them should reveal the motivation of our research and the problem with capital flows we wish to study. First, emerging economies in Central and Southern Europe faced a wide gap after about half of century of central planning system. Closing this gap could have been achieved by either internal process of capital accumulation and modernization, or by importing all the missing factors of production. The first way was rejected as unfeasible, time-consuming and slow in terms of the catch-up process. The other way to close the development gap required importing investment goods and capital. Together with exploding consumption of imported products, this situation resulted in serious deterioration of foreign assets depleting reserves in many cases. This, in turn, led to few sudden stops in post-Communist countries and the Czech Republic in 1994 is a prominent case here. Acceptance of large current account deficit was therefore justified by expectations concerning future effects of quick, foreignfinanced economic transformation. After several years of hard-time market reforms, and associated current account deficit, emerging economies were expected to enter a path of long-term dynamic growth. This would allow for turning the deficit into a surplus and help to repay foreign liabilities 
created over the transformation period. Such scenario draws heavily on an assumption that foreign capital inflows finance pro-growth initiatives and not current consumption, private and public alike. This was a story of some, but not all, emerging economies in Central and Southern Europe. Many countries failed in efficient reforming production capacity and are problematic members of the EU after about 24 years since entering transformation period. As a consequence, the credit provided by external sources in the form of accepting permanent balance of payments imbalance, has been wasted. In addition, both the debtor countries and creditor ones alike experienced adverse effects of the financial turmoil. Neglecting real reforms and referring to creative accounting in public finance instead of fiscal consolidation is, however a much more common sin in the European Union, not restricted to the new member states of the $1^{\text {st }}$ May 2004. Our story offers an alternative approach to understanding a fraction of the debt created due to Common Market and European Financial Area. We focus on countries suffering from excessive external private debt that have been members of the Eurozone.

\section{The Situation of Financial Flows in Creditor and Debtor Countries}

The debt crisis in Europe that emerged in 2009 did not hit emerging economies as much as some of the so-called oldEU-member states (Blanchard, 2007). Continuous foreign liabilities accumulation by Portugal, Ireland, Italy Greece and Spain (PIIGS) was however of diverse nature and exposed these countries to diverse risks and different adverse effects. Therefore, analyzing these cases cannot be a joint exercise. The pattern of bilateral net investment positions in Figure 1 shows diverse engagement of EU-creditors (Germany, France, and the UK) in financial net flows to EU-debtors (Portugal, Ireland, Italy, Greece, and Spain.

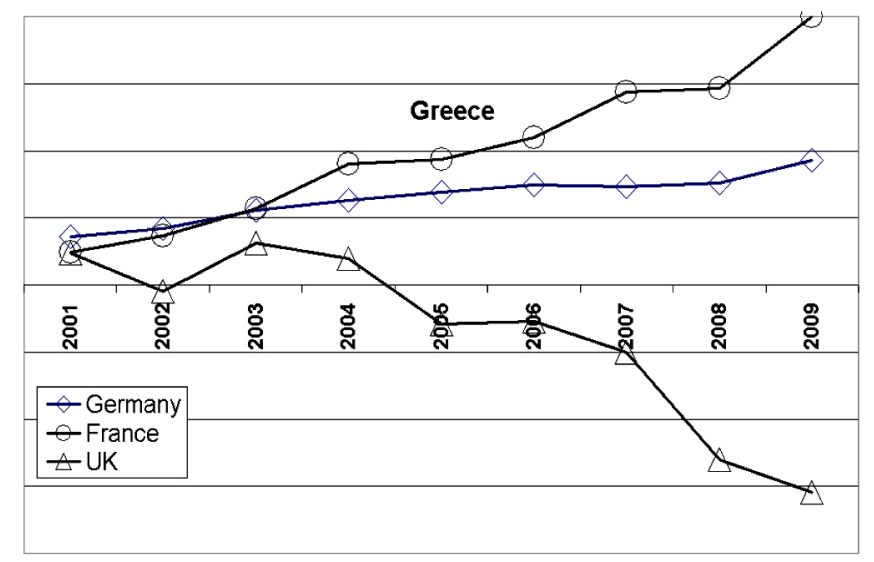

Figure 1. Bilateral net investment positions of Germany, France and the UK with Greece 2001-2009

Source: Authors, on the basis IMF database on Trade and Investment.

In case of Greece, all of the EU-creditors used to have positive net investment positions until 2004, with the UK moving below the line, while France and Germany continued to extend credit to Greece. France outpaced Germany in financing Greek excessive domestic absorption.

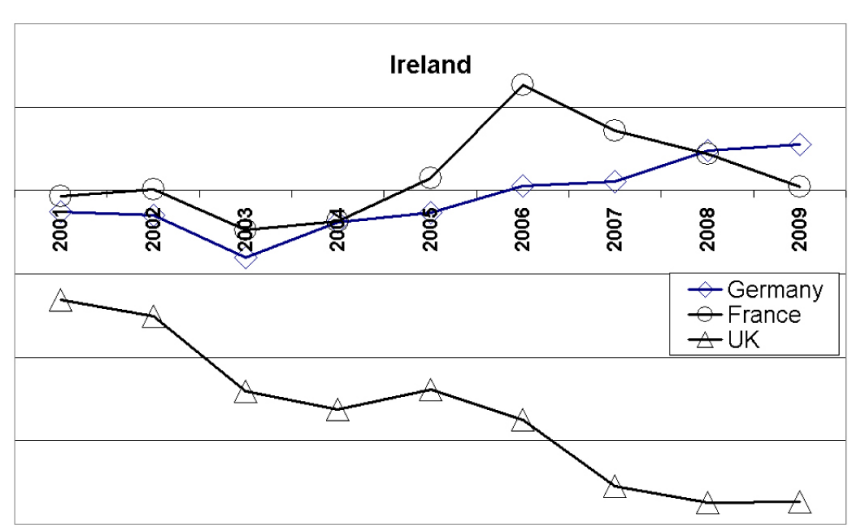

Figure 2. Bilateral net investment positions of Germany, France and the UK with Ireland 2001-2009

Source: Authors, on the basis IMF database on Trade and Investment.

Ireland seems to be a very different case, from other of the EU-debtor countries. The net positions with Germany and France seem to be balances, while the UK is a net debtor for the whole period covered by the empirical analysis.

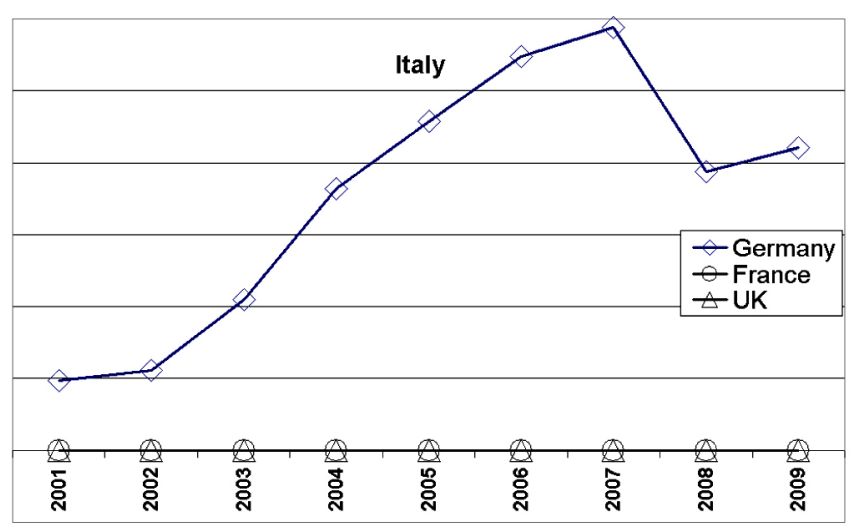

Figure 3. Bilateral net investment positions of Germany, France and the UK with Italy 2001-2009

Source: Authors, on the basis IMF database on Trade and Investment.

Italy is a country that depends heavily on financial flows coming from Germany. Other EU-creditors maintain rather balanced net positions, and therefore are relatively immune to domestic developments in Italy, in comparison with Germany.

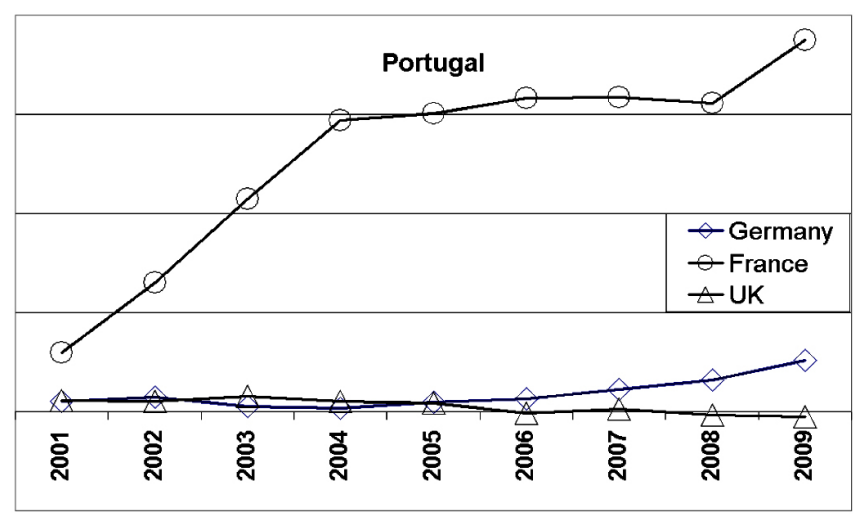

Figure 4. Bilateral net investment positions of Germany, France and the UK with Portugal 2001-2009 Source: Authors, on the basis IMF database on Trade and Investment. 
Portugal shows strong financial dependence on financial flows coming from France. The period preceding the debt crisis (2004-2008) witnessed stabilization of substantial positive net investment position with this particular country. Following year 2008, France continued to increase its net creditor position with Portugal. In the same time the UK and Germany maintained balanced net investment positions with Germany moving systematically above the line from 2004.

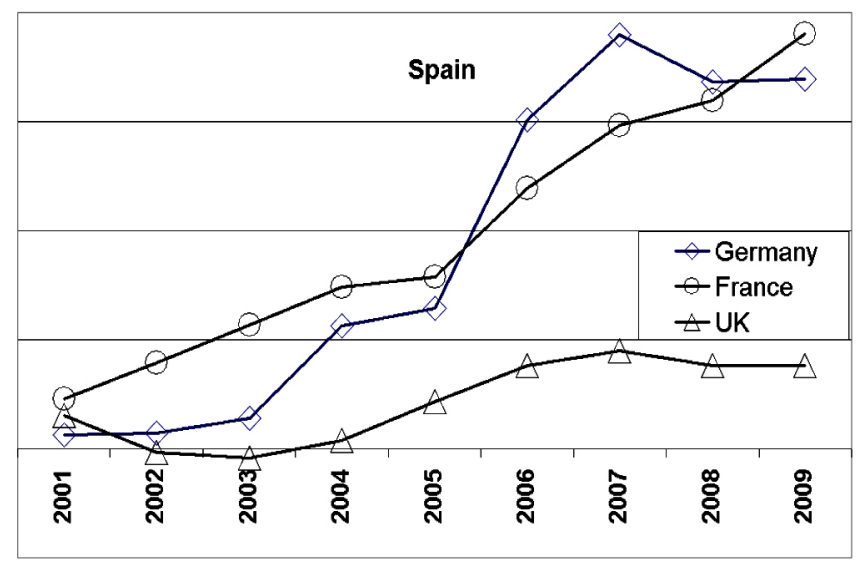

Figure 5. Bilateral net investment positions of Germany, France and the UK with Spain 2001-2009

Source: Authors, on the basis IMF database on Trade and Investment.

Spain falls perfectly into the stylized facts scenario we try to present here. All of the EU-creditor countries start dynamic growth in terms of net investment positions with Spain from 2004 to 2009. Both, Germany and France, hold the leader position, providing substantial amount of foreign financing to this particular EU-debtor. As a consequence, they are most exposed to risk of default of Spanish borrowers, but the UK is not free from this problem too.

What may be of common root here is the fact that, according to Giavazzi \& Spaventa (2011), creation of foreign liabilities was matched by current consumption spending and investment expenditure in the non-traded sector, namely real estate. Eichengreen (2010) offers a similar observation. As such, there were no actions that would result in building up and expanding repayment potential of economies welcoming foreign capital inflows. Therefore, the rationale for accepting external imbalances, presented above for emerging economies, was not present in case of the PIIGS group.

Presentation of stylized insights about creditor-debtor relationship considering investments in real estate in PIGS countries. What made the creditors extend financing over so many years despite there were no signs of fiscal and private sector consolidation?

We offer a quite different explanation for the observed pattern of capital flows within the European Union, and we 'blame' the new member states of the 2004, and the EU common market mechanism. The story begins with an observation that a panic or any other herd behavior is initiated by few but becomes a problem when undertaken by majority that is not fully aware of the underlying situation, and is not prepared for consequences of their own actions.

From the moment of the EU enlargement on the $1^{\text {st }}$ of May 2004 , ten new member states entered a period of equalizing marginal utility of assets they hold. With the full economic integration, the Common Market offered possibility of international diversification that was not available before this systemic change. Wealthy citizens of the new member states started to purchase real estate in attractive locations in Portugal, Italy, Greece and Spain. Therefore, we claim that the real asset prices boom in Southern regions of the EU was initiated by foreigners holding sufficient funds to purchase even high-value real assets without recourse to creation of liabilities. There was an additional factor that made this scenario much more common and attractive not only for the wealthiest citizens from the new member states. The period 2004-2008 witnessed a systematic, stable and continuous appreciation of national currencies against the Euro, in countries adopting free float exchange rate regime. This nominal development made all acquisitions of foreign assets in Spain, Portugal, Italy and Greece much cheaper until the late third quarter of 2008 .
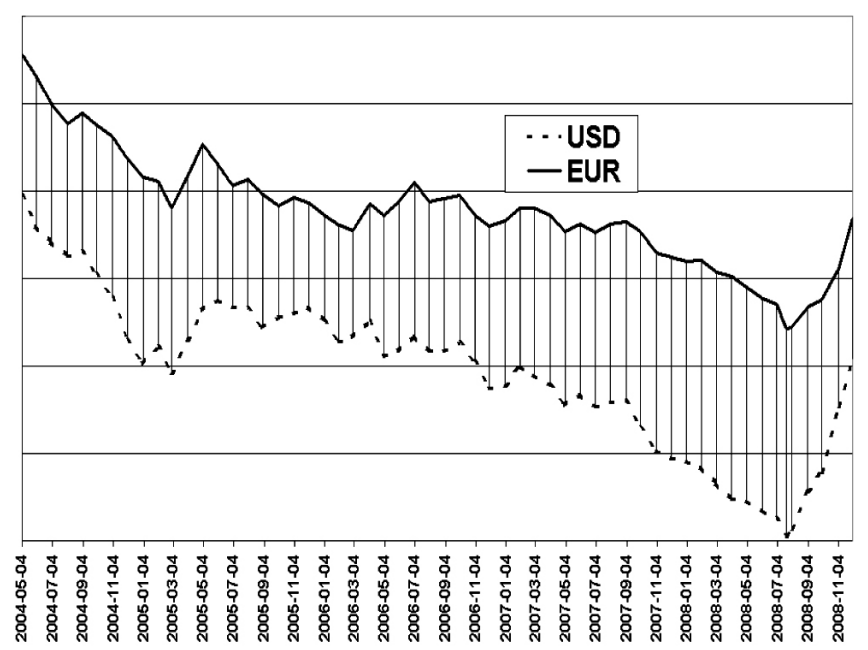

Figure 6. Nominal exchange rate against Euro and the USD of a new member state ${ }^{1}$ national currency in the period from 2004-05-01 to 2008-12-04

Source: Authors, on the basis of a National Bank of Poland exchange rate database.

If these additional real estate transactions were restricted to foreigners only, the scale and scope of the debt crisis of 2009 would be much more modest. However, this was not the case. Locals observed this behavior and interpreted economic consequences of increasing demand with the long-run fixed supply of land available and the fixed supply of residential real estate in the short- to mid-term. Expecting that inflow of foreign direct residential investment from the new member states after May 2004 will result in appreciation of real estate, locals started to take long positions in such assets. This investment strategy was based, however, on private foreign debt creation, as there was insufficient domestic capital pool. Local banks were eager to extend financing for real estate investment observing positive rends in the collateral value due to real asset inflation. It refers both to financing of outright acquisitions of existing houses and condominiums, and to financing construction of such. For

1 As a „new member state“ authors interpret countries which joint EU in 2004 as they have experienced systematic and permanent appreciation of national currencies, until mid-2008. 
almost four years (2004-2008) this investment strategy by residents of Southern regions delivered a handsome rate of return. It became a self-feeding process. Due to long-term and systematic appreciation of real assets it encouraged even more new debt-financed investments. Depreciation of the Euro created returns differentials that were increasing until late 2008 (Curcuru, Thomas, Warnock 2013). Most of investments in real estate were based on borrowing foreign capital via local banks. International capital continued to flow within the European Union.

Summarizing, the stylized insights we offer as the explanation of the underlying mechanism of the path to the $E U$ private debt crisis of 2009 are as follows. Step one: citizens of the new EU member states of 2004 started to diversify asset portfolios with real assets available in attractive locations in Southern regions of the EU. Motivation for investment in foreign real estate came from the classical 'equalization' of marginal utility of holdings of each category of available assets. In addition, the motivation was enhanced by systematic and persistent appreciation of national currencies against the Euro. Original purchases were made without recourse to debt financing due to two main reasons. First, buyers were foreigners and local banks found it problematic to extend mortgages to such customers. Second, banks at home countries (new member states) refrained from providing financing for real estate investments in remote regions. As a consequence, we were able to observe a growing inflow of foreign direct investment in real estate markets in Portugal, Italy, Greece and Spain from the late 2004. It is indicated by a transition in correlation between average rates of change of direct investment in the reporting economy, and portfolio investment in debt instruments, other investment (liabilities), and other investment (liabilities) of other sectors (non-banks).

From the 2004 other investment liabilities mimic more closely developments in the foreign direct investment with the correlation reaching almost 0,8 after only 0,73 in the preceding period (see Table 1). Simultaneously, significance of sectors responsible for creating foreign liabilities in the form of other investment also changes. This is reflected in increase in the correlation between the other investment liabilities (total) and other investment liabilities of "other sectors", namely households from 0,53 to 0,77 . While the FDI developments were not significantly matched by private nonfinancial sector foreign liabilities before 2004 (correlation at 0,28 ), afterwards the relationship is much more pronounced with correlation coefficient at almost 0,54 .

Table 1. Correlation coefficients for quarterly changes in the IIP for the period 1999Q1-2004Q1 and 2004Q2-2009Q2 for Spain

\begin{tabular}{|l|c|c|c|c|c|}
\hline \multicolumn{1}{|c|}{ 1999-2004 } & FDI & PI Debt & OI Liab. & OI Oth.Sec. \\
\hline FDI & 1 & 0,74 & 0,73 & 0,28 \\
\hline PI Debt & & 1 & 0,53 & 0,12 \\
\hline \multicolumn{2}{|c|}{ OI Liab. } & & \multicolumn{1}{c|}{1} & 1 & 0,53 \\
\hline \multicolumn{2}{|c|}{ OI Oth.Sec. } & & & & 1 \\
\hline 2004-2009 & FDI & PI Debt & OI Liab. & OI Oth.Sec. \\
\hline FDI & 1 & 0,56 & 0,78 & 0,53 \\
\hline PI Debt & & 1 & 0,42 & 0,56 \\
\hline OI Liab. & & & 1 & 0,77 \\
\hline OI Oth.Sec. & & & & 1 \\
\hline
\end{tabular}

Source: Authors, on the basis of the IFS database, IMF, Washington D.C.
Step two: residents of Southern EU regions observed additional demand for real estates. This, in turn, created appreciation expectations. Locals wished to benefit using speculation scheme. They took long positions in the real estate. However, these speculative transactions were mostly based on borrowed funds. In countries with insufficient domestic savings, local banks initiated foreign capital inflows from other EMU member states.

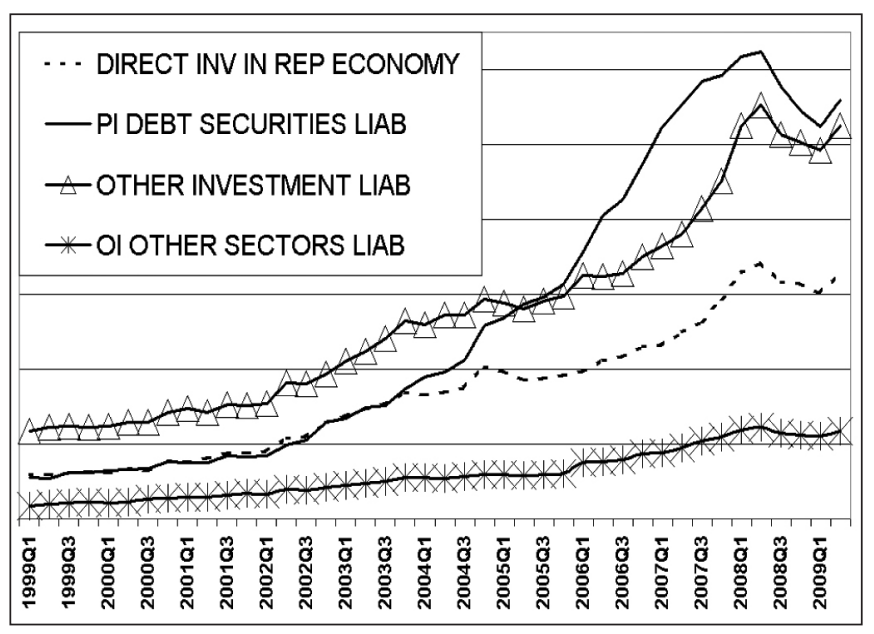

Figure 7. IIP categories quarterly, Spain 1999Q1-2009Q2

Source: Authors, on the basis of the IFS database, IMF,

Washington D.C.

Foreign liabilities systematically grew (as seen in Figure 7). There was no exchange rate risk associated with this borrowing. Propensity to use foreign financing was therefore higher than otherwise.

Step three: real estate market in Southern regions experienced boom. It was started by cash holders (foreigners) and became leverage-fuelled by residents, but borrowing flew from abroad.

Step four: reversing appreciation trend of national currencies in late 2008 and severe depreciation in mid-February 2009 resulted in making real estate investment for the new EU-member states citizens unattractive and relatively more expensive. External buyers disappeared from the real estate markets. The appreciation impulse for real assets associated with foreigners vanished. Locals in Southern regions found themselves in long positions in significantly inflated real assets without any chance for recovering the original cost due to deficient demand. On the other side of their balance sheets they recognized liabilities of stable nominal value, for which collateral value shrank. There is common perception in the literature, and at European institutions that the valuation effects are significant in scale and scope, when wealth of nations is considered. One may find supporting evidence and interpretations in Galstyan \& Lane (2013), European Commission (2010), Coeurdacier \& Martin (2009), and Gourinchas, Rey, \& Truempler (2012). Due to the debt crisis in Europe one may suggest a substantial shift of the wealth from EU-creditor countries to EU-borrowers due to investment in real estate. Inflated prices of real assets resulted in transferring additional value in excess of the intrinsic value, and recover of this excess is no longer possible as the downward trends in prices continue. In the same time, EU-borrowers postpone and reschedule repayment of loans extended before the crisis 
of 2009, so the lenders do not recover amounts provided and suffer from adverse wealth effects.

\section{Conclusions}

The authors have found that there exist different bilateral engagement (net investment positions) between the EUcreditors (Germany, France, and the UK) and EU-borrowers (Greece, Ireland, Italy, Portugal, and Spain). Mainly France finances Portugal. Spain is financed by all three EU-creditors with the UK least engaged. Germany finances Italy, while Ireland has small scope of financing by Germany, and provides substantial credit to the UK, just like Greece. This situation we find confusing to some extent. Data availability makes it difficult to proceed with in-depth studies of the problem in most cases. However, it has been possible to find support for our claims, and to show a design of the herd behavior initiated by citizens of the New Member States of 2004.

The authors tried to present an alternative scenario as an explanation of the mechanism behind the process of foreign liabilities accumulation in the EU before the debt crisis of 2009. In order to show the dynamics of intra-EU financial flows we have used information about bilateral investment positions for pairs of countries, EU-creditors and EU-debtors. In addition, we looked also at the aggregated IIP categories, without geographical decomposition to support our claims about the role of the Common Market and of herd behavior before and after New Member States of 2004 joined the EU. The stylized insights about creditor-debtor relationship considering investments in real estate in PIGS countries find strong support in empirics, and Spain is the best match for the story authors offer. Other of the EU-borrowers also present support for the proposed scenario. However, they show the posed trends to a lesser extent, as the scope of foreign direct investment in real estate markets has been relatively smaller in Italy, Portugal, Greece and Ireland.

Concluding, it is a key to stress few points. The Common Market mechanism allows for asset portfolio realignment for new entrants and old EU-members. In spite of fear disseminated in the new member states by anti-EU propaganda, the scope of buying out land and property has been of small scale. Serious problems, according to idea proposed, have been caused by opposite financial flows of direct investment in real estate, originating from the New Member States and arriving to Spain, Portugal, Greece and Italy. These financial flows spawned not only herd behavior among locals in Southern regions, but also initiated foreign borrowing to explode to finance real estate markets boom. With the foreigners discouraged by global financial turmoil in 2008/2009, external demand for residential assets vanished. It left locals with portfolios of inflated, but shrinking, real assets and fixed value of associated (foreign) liabilities that sponsored speculative strategies.

Ideas for further research. Analysis of available economic policy options to solve the arouse problems has been beyond the scope of this paper. However, it has been already valuable to shed some light on an alternative mechanism that describes behavior of some agents creating foreign liabilities that, in turn, lead to debt crisis. There have been several areas of potentially interesting and valuable further research. One can list here a deeper study of developing relationship between foreign investment in real estate and domestic credit extended on the basis of externally borrowed funds. Another direction should be a study on transfers of the wealth between nations and shall focus on the scope of valuation trends between real domestic assets purchased on the basis of foreign liabilities, and the value of such within the Euro Area.

\section{References}

Barnes, S. (2010). Resolving and Avoiding Unsustainable Balances in the Euro Area. OECD Economics Department Working Paper No. 827.

Blanchard, O. (2007). Current Account Deficits in Rich Countries. IMF Staff Papers 54(2), 191-219. http:// dx.doi.org/10.1057/palgrave.imfsp.9450013

Borio, C., McCauley R. \& McGuire P. (2011). Global Credit and Domestic Credit Booms. BIS Quarterly Review (September), 43-57.

Brown, M. \& Lane Ph. R. (2011). Debt Overhang in Emerging Europe? World Bank Policy Research Working Paper No. 5784.

Coeurdacier, N. \& Martin Ph. (2009). The Geography of Asset Trade and the Euro: Insiders and Outsiders. Journal of the Japanese and International Economies 23(2), 90-113. http://dx.doi.org/10.1016/j. jjie.2008.11.001

Curcuru, S. E., Dvorak T. \& Warnock F. E. (2008). CrossBorder Returns Differentials. Quarterly Journal of Economics 123(4), 1495-1530. http://dx.doi.org/10.1162/ qjec.2008.123.4.1495

Curcuru, S. E., Thomas C. P. \& Warnock F. E. (2013). “On Returns Differentials". 1077. Available from internet: http://www.federalreserve.gov/pubs/ifdp/2013/1077/ ifdp1077.pdf. http://dx.doi.org/10.3386/w18866

Deseatnicov, I. \& Akiba, H. (2013). Reconsideration of the Effects of Political Factors on FDI: Evidence from Japanese Outward FDI. Review of Economics \& Finance, Better Advances Press, Canada, vol. 3, February, 35-48.

Eichengreen, B. (2010). Imbalances in the Euro Area. mimeo, UC Berkeley. Retrieved April 14, 2014, from http://emlab.berkeley.edu/ eichengr/Imbalances_Euro_ Area_5-23-11.pdf

European Commission (2010). The Importance of Valuation Effects for External Asset Positions in the Euro Area. Quarterly Report of the Euro Area 9(1), 29-36.

Forbes, K. \& Warnock F. E. (2012). Capital Flow Waves: Surges, Stops, Flight and Retrenchment. Journal of International Economics 88(2), 235-251. http://dx.doi. org/10.1016/j.jinteco.2012.03.006

Galstyan, V. \& Lane, Ph. R. (2013). Bilateral Portfolio Dynamics During the Global Crisis. European Economic Review 57(1), 63-74. http://dx.doi.org/10.1016/j. euroecorev.2012.10.002

Geanakoplos, J. (2009). The Leverage Cycle. NBER Macroeconomics Annual 24, 1-66.

Giavazzi, F. \& Spaventa, L. (2011). Why the Current Account Matters in a Monetary Union in The Euro Area and The Financial Crisis (Miroslav Beblavy, David Cobham and L'udovit Odor, editors). Cambridge University Press, 59-80. 
Gourinchas, P.-O., Rey H., \& Truempler K. (2012). The Financial Crisis and the Geography of Wealth Transfers. Journal of International Economics 88(2), 266-285. http://dx.doi.org/10.1016/j.jinteco.2012.05.008

Lane, Ph. R. (2006). The Real Effects of European Monetary Union. Journal of Economic Perspectives 20, 47-66. http://dx.doi.org/10.1257/jep.20.4.47

Lane, Ph. R. (2010). International Financial Integration and the External Positions of Euro Area Countries. OECD Economics Department Working Paper No. 830. http:// dx.doi.org/10.1787/5km33sqg0m9s-en

Lane, Ph. R. (2012). The European Sovereign Debt Crisis. Journal of Economic Perspectives 26(3), 49-68. http:// dx.doi.org/10.1257/jep.26.3.49

Lane, Ph. R. \& Milesi-Ferretti, G. M. (2012). External Adjustment and the Global Crisis. Journal of International Economics 88(2), 252-265. http://dx.doi. org/10.1016/j.jinteco.2011.12.013
Lane, Ph. R. (2013). Capital Flows in the Euro Area. European Economy, Economic Papers No. 297.

Reis, R. (2013). The Portuguese Slump and Crash and the Euro Crisis. Brookings Papers on Economic Activity, Issue 1, no. 46, 143-210. http://dx.doi.org/10.1353/ eca.2013.0005

Spiegel, M. (2008). Monetary and Financial Integration in the EMU: Push or Pull? Review of International Economics 17(4), 751-776. http://dx.doi.org/10.1111/ j.1467-9396.2009.00847.x

Tirole, J. (2012). Country Solidarity, Private Sector Involvement and the Contagion of Sovereign Crises. Retrieved April 14, 2014, from http://idei.fr/doc/by/tirole/ countrysolidarity0919.pdf

European Community, The Treaty of Rome, 1957.

Waysand, C., Ross, K. \& De Guzman, J. (2012). European Financial Linkages: A New Look at Imbalances. IMF Working Paper No. 10/295.

The article has been reviewed. Received in April, 2014; accepted in June, 2014. 